\title{
Xanthogranulomatous hypophysitis due to craniopharyngioma rupture: A case report
}

\author{
Martha Lilia Tena-Suck ${ }^{1}$, I saac J air Palacios-Ortiz ${ }^{2}$, Ernesto Martinez ${ }^{2}$, Citlaltepelt Salina-Lara ${ }^{1}$, \\ Carlos Sánchez-Garibay ${ }^{1}$
}

1. Department of Neuropathology, National Institute of Neurology and Neurosurgery. México City, México. 2. Service of Neurosurgery. National Institute of Neurology and Neurosurgery. México City, México.

Correspondence: Martha Lilia Tena-Suck, M.D., Ph.D. Address: Escuela Superior de Medicina, Sección de Estudios de Postgrado, Instituto Politécnico Nacional \& Departamento de Neuropatología, Instituto Nacional de Neurología y Neurocirugía. Insurgentes Sur 3877, México D.F., México. E-mail: mltenasuck@gmail.com

Received: June 9, 2015

DOI : $10.5430 /$ crcp.v2n4p30
Accepted: June 27, 2015

URL: http://dx.doi.org/10.5430/crcp.v2n4p30

\section{Abstract}

Introduction: Hypophysitis is a rare, inflammatory disorder of the pituitary that mimics neoplastic lesions resulting in anterior and posterior pituitary dysfunction.

Presentation of case: We present a 36-year-old woman who presented with chronic headaches and was found to have a pituitary mass on MRI, suggested of craniopharyngioma, and the histological inspection showed a piloide gliosis, one year ago. She continuing with visual disturbance and recurrence was suspected and she was operated to craniopharyngioma. After that, she showed clinical and radiologically symptoms of recurrence and was reopeated which biopsied was reported as xantogranulomatosous hypophysitis.

Discussion: This woman illustrates a rare pituitary pathology presented with a literature review of published patients describing xanthomatous hypophysitis. In this case we describe a patients with xanthogranulomatous hypophysitis (XGH) demonstrating post-surgical procedure of craniopharyngioma resection.

Conclusion: Xantomagranulomatous reaction was due to rupture of cyst walls of craniopharyngioma or natural immunological and inflammatory mechanism of reduction of tumor growth and progression of disease caused by extravased cyst content into the adjacent gland and favoring the reduction or regression of tumor.

\section{Key words}

Pituitary hypophysitis, Craniopharyngioma, Rupture of tumor, Giant cells, Cholesterol cleft, Oil machinery fluid of Craniopharyngiomas

\section{I ntroduction}

Pituitary hypophysitis $(\mathrm{PH})$ is very rare inflammatory disorder that may present both clinically as well as, radiologically features as a neoplastic tumors ${ }^{[1]}$. Clinically, it is associated with headaches, and visual disturbance due to the local mass effect and compression of the optic chiasm also pituitary dysfunction has been reported as secondary to inflammatory infiltration ${ }^{[1]}$. Generally Pituitary adenomas (PA) is diagnosed ${ }^{[1]}$. Infiltration of both the hypophyseal parts; adeno- and neuro-hypophysis explains the clinical correlation with headaches, anterior pituitary dysfunction and diabetes insipidus ${ }^{[2]}$. 
The difference in presentation between paediatric and adult patients reflects the functional impact of pituitary hormone deficiency ${ }^{[2]}$. MRI demonstrated mixed signal intensities on T1- and T2-weighted sequences, suggesting PA ${ }^{[1,2]}$.

Tashiro T et al. ${ }^{[3]}$, described the histologically finding of PH and divided into the five categories: lymphocytic (LH), granulomatous $(\mathrm{GH})$, xanthomatous $(\mathrm{XH})$, necrotizing $(\mathrm{NH})$ and xanthogranulomatous hypophysitis (XGH), with the latter being a mixture of the xanthomatous and granulomatous subtypes. They are also classified as either adenohypophysitis (AH) or infundibulo neurohypophysitis based on their structural location and areas of infiltration ${ }^{[3]}$, connecting of multinucleated giant cells, epithelioid cells and lymphocytic infiltration, in totaling, and cholesterol clefts have been reported within these tissue samples ${ }^{[3]}$.

The pathogenesis of PH still remain controversial, PH may progress spontaneously or as a secondary reaction to hemorrhage, tissue necrosis or plain inflammation following leak of cystic contents into the adjacent tissue in pre-existing lesions such as craniopharyngioma (CPs) ${ }^{[4,5]}$, pituitary adenomas or Rathke's cleft cysts (RCC) ${ }^{[6]}$, or a systemic condition with autoimmune aetiology ${ }^{[7]}$, as well as due to hypothyroidism, antiphospholipid syndrome and panhipopitituarism, Mikulicz's disease, primary Sjögren's syndrome, corticotrophin deficiency, post pituitary adenoma, association to primary pituitary lymphoma, post treatment with azathioprine, ipilimumab and CTLA-4, and also, post-partum have been reported, or may be due to multiorgan systemic participation such as tuberculosis, sarcoidosis and other granulomatosis diseases ${ }^{[8-13]}$, etc. A high level of clinical suspicion of inflammatory conditions is essential for correct diagnosis and best management, radical surgery is the optimal treatment and spreads an outstanding prognosis with not recurrence ${ }^{[1]}$.

The aim of this study was case report of a 36-years-old female with craniopharyngioma resected one year ago, and she presented tumoral regrowth and abscess vs. pituitary adenomas was suspected by MRI. Xanthogranulomatous hypophysitis was diagnosed due to rupture of craniopharyngioma.

\section{Clinical case}

A 36-year-old female with a history of father and mother with DM2 and two brothers with seizures. Menarche at 12y, pregnancies 6 , menopause at age 28. She was diagnoses as hypothyroidism 12 years ago and treated with levothyroxine $100 \mathrm{mg}$ per day. She began its current condition with headache, nausea and developed a decrease in peripheral vision in the right eye and progressive loss of vision of right eye. In 2014 she was admitted in our institution with headache and bilateral amaurosis. The MRI showed a partially calcified slightly enhancing intrasellar mass with suprasellar extension which was slightly hyperintense on T1 images and hypointense on T2 images, a sellar lesion suggestive of pituitary adenoma (see Figures 1a-1c). Complete resection of the tumor mass using trans-sphenoidal approach was performed. The report of the firth biopsy was a piloide gliosis (see Figures 1d-1f), and a second surgery was completed and the histopathological record was a small fragment of squamous epithelium suggestive of craniopharyngioma (Figures not seen). Her vision has improved slightly and MRI revealed no lesion.

In May 2015, she continuous with headache and visual disturbances, and the MRI showed a sellar mass measuring $35 \mathrm{~mm}$ $\times 35 \mathrm{~mm} \times 27 \mathrm{~mm}$ (see Figures 2a-2c), that showing a thickened capsule and a homogeneous inner highlighted (see Figures 2d-2f), a pituitary adenoma diagnosis was suspected. She was transsphenoidal surgical procedure with resection of the tumor undergone. In the surgical process coffee-like serous and mucinous-yellowish material was evacuated and curettage of the wall of tumor and the yellowish hard mass and soft membranous tissue were removed. The crops grown in this secretion were negative. For histopathology several irregular soft tissue fragments that measured $20 \mathrm{~mm} \times 15 \mathrm{~mm} \times$ $10 \mathrm{~mm}$ yelloshih and coffee was sent. Histologically was observed residuary of adenohipophysis (see Figure 3a), surrounded by a thick fibrous connective tissue of pseudocapsule (see Figure 3b) with dense inflammation reaction (see Figure 3c), giant multinuclear cells (see Figure 3d), and cleft of cholesterol (see Figure 3e), and hemosiderophages were also observed. Focus of squamous epithelium were noted (see Figure 3f). In other hang abundant macrophages with foamy cytoplasm with proteinaceous yelloshih material was observed (see Figure 3g), this material was also observer in pituitary cells (see Figure 3h), as well, as in the pseudocapsule (see Figure 3i). The final histological diagnosis was a xanthogranulomatous hypophysitis.

Published by Sciedu Press 

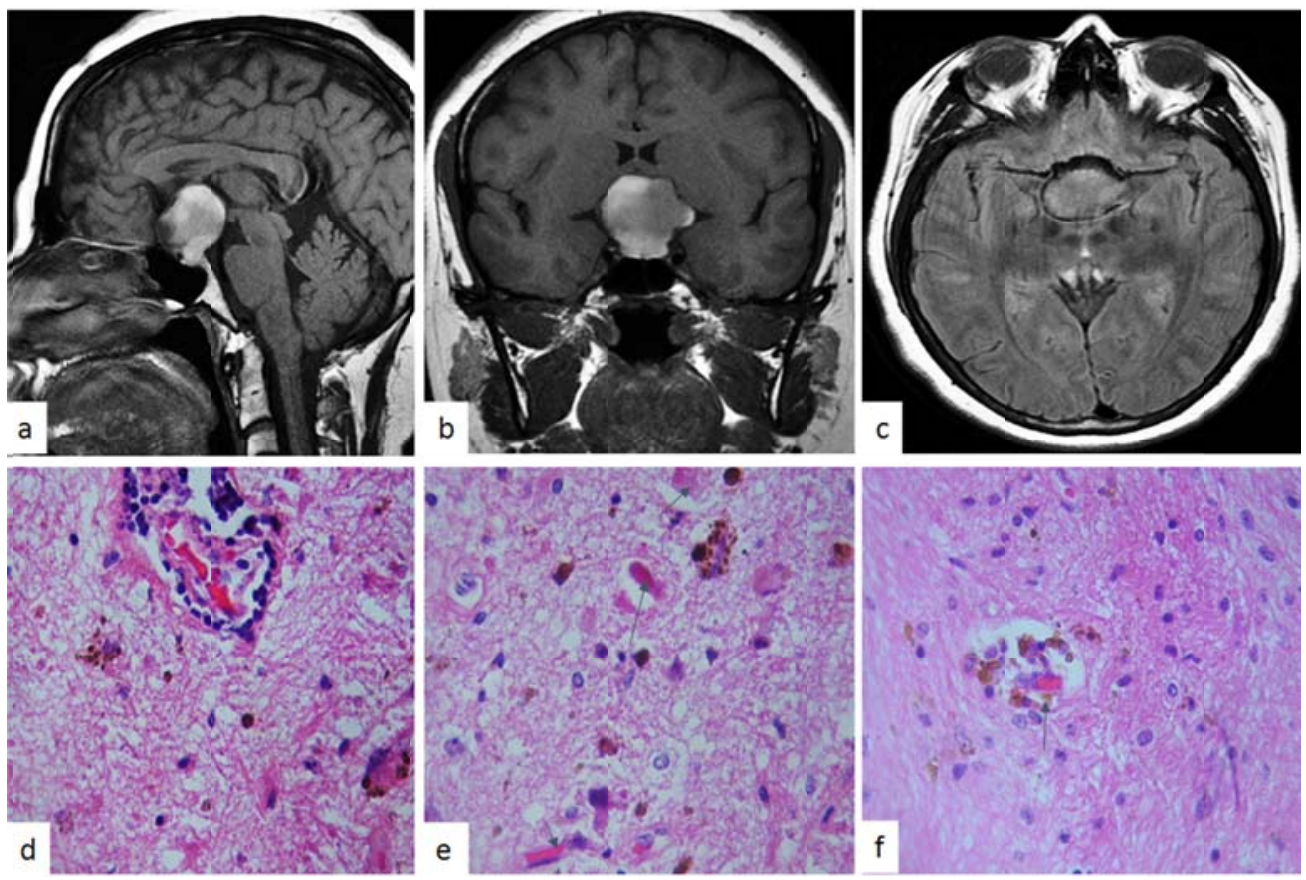

Figure 1. MRI of the pituitary tumor (a) we observed the MRI which was taken before the firth surgery (b) without contrast in sagittal, coronal (b) and axial splices we can observed an selar and suprasellar tumor with hyperintense behavior and in (c) observed superior desplacenment of the optic chiasm third ventricle and the willis circle. Histopathology of the first biopsy. (d) Reactive gliosis and Rosenthal fibers formation were observed with perivascular inflammatory cells. (e) and (f) showed the Rosenthal fibers and abundant macrophages with foamy and lipid vacuoles and yelloshih dense material, or lipid-laden histiocytes. The arrows showed the RFs.
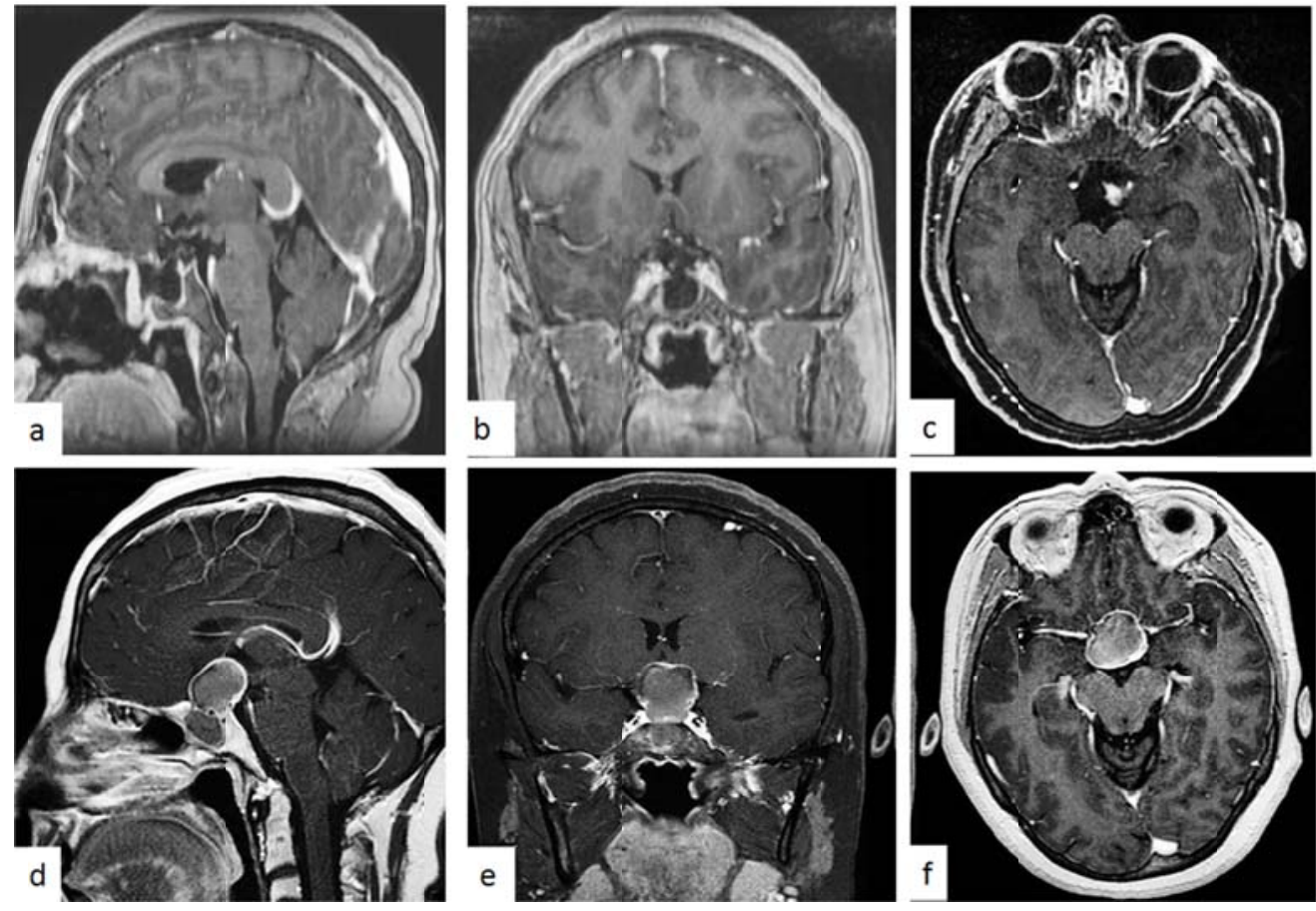

Figure 2. Second MRI images (a) observed in sagittal, coronal (b) and axial Slices (c), the postoperative changes in the sellar and suprasellar region, that showed a little residual tumor which is attached to the left Internal Carotid artery. (d) Observed the tumor recurrence in the sellar and suprasellar region, which hiperintense behavior, (e) and (f) observed and a ring-shaped reinforcement with the administration of contrast. 

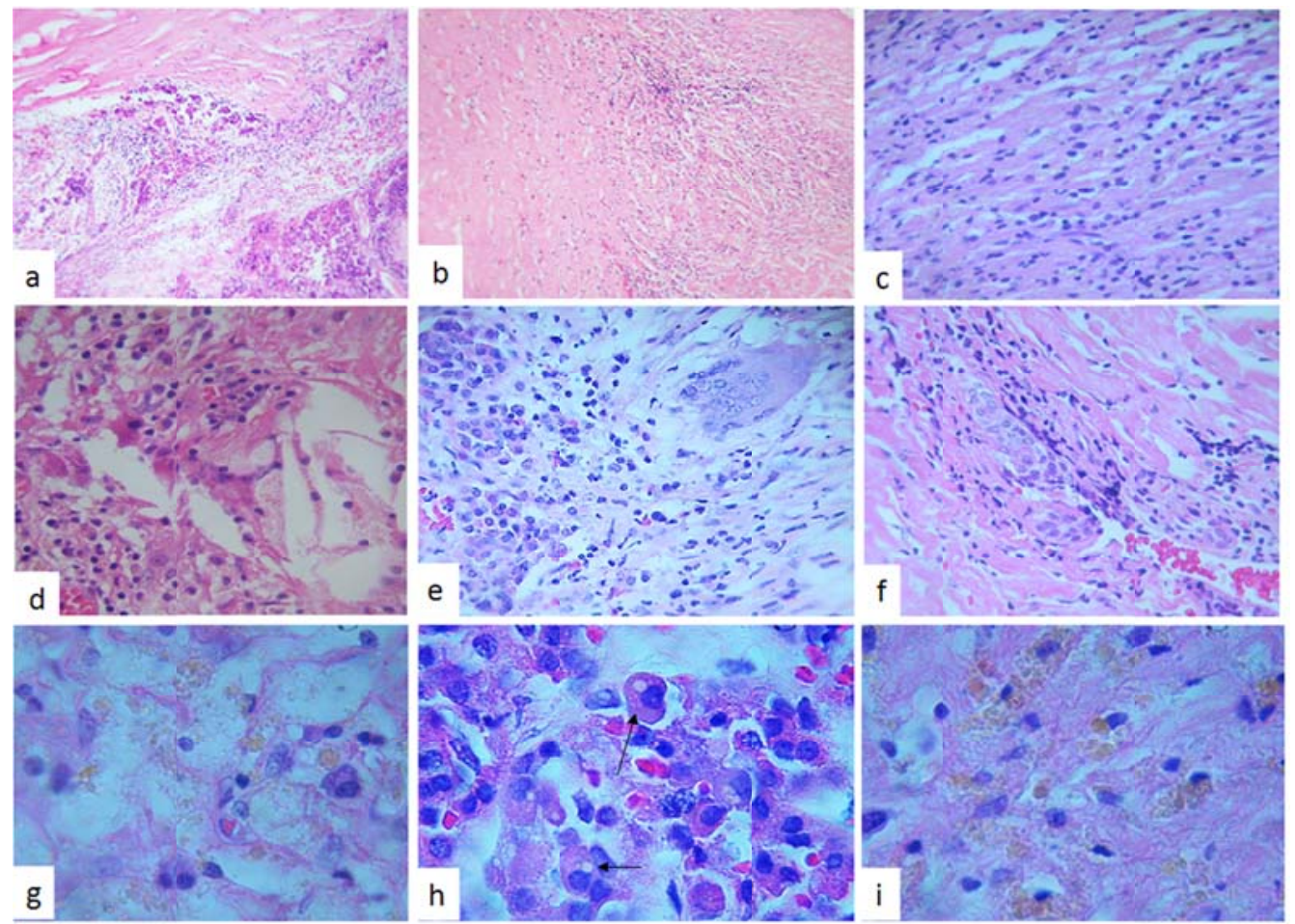

Figure 3. Histopathological features of the second biopsy. (a) Rest of adenohipophysis normal gland, (b) was surrounded by dense fibrous connective tissue that forming a pseudocapsule $(H \& E \times 200)$, that showed in (c) dense inflammation, (d) giant multinuclear cells, and in (e) cleft of cholesterol. (f) In the fibrous pseudocapsule rest of squamous epithelium were observed. (g) $(\mathrm{H} \& \mathrm{E} \times 400)$. Also abundant macrophages with foamy and lipid vacuoles and yelloshih dense material, or lipid-laden histiocytes in (h) this material was observed in pituitary cells , the arrows showed the presence of charged lipid vacuoles and the material, and in the fibrous pseudocapsule was observed in (i) (H\&E ×100).

\section{Discussion}

PH that may present both radiologically and clinically and as a neoplastic lesion in especial a pituitary tumor ${ }^{[1,2]}$, and have been separated into the five categories: $\mathrm{LH}, \mathrm{GH}, \mathrm{XH}, \mathrm{NH}$ and $\mathrm{XGH}$, with the latter being a mixture of the xanthomatous and granulomatous subtypes ${ }^{[3]}$. All forms described have in common the presence of lymphocytes, giant cells and macrophages ${ }^{[4]}$, those lesions are clinically and radiologically trouble to difference from CP and Ranke cyst to XGH ${ }^{[3]}$.

PH is characterized by pituitary gland infiltration of lymphocytes, macrophages, and plasma cells that could lead to loss of pituitary function ${ }^{[3]}$. In the surgical procedure can showed yellowish firm tissue and xanthochromic fluid ${ }^{[3]}$. $\mathrm{XH}$ is characterized by an infiltration of lipid-laden histiocytes, also known as xanthoma cells ${ }^{[1-3]}$.

XGH is clinically and radiologically and also histologically indistinct of CP, may either be primary with an autoimmune aetiology and can occur in isolation or as a part of autoimmune systemic disease or secondary as a reactive degenerative response to a preexisting epithelial lesion ${ }^{[8,9]}$. A combination of fibrous scar tissue with chronic inflammation, highlighted by CD45 immunostaining, and widely calcified necrotic debris, including cholesterol crystals reliable with a diagnosis of xanthogranuloma ${ }^{[1-4]}$.

Giant cells (GC) are no specific of XH or XGH, or Tuberculosis, syphilis, or sarcoidosis neither other systemic granulomatous diseases have also been considered as etiological factors in pituitary granulomas ${ }^{[1-4]}$. As well as, the giant cell granulomatous hypophysitis granulomatous lesion is collected of epithelioid cells, Langham's multinucleated giant cells, lymphocytes and plasma cells. 
Plasma cell granuloma is one of the subtypes of inflammatory pseudotumor, is non-neoplastic proliferation of plasma cells. Immunohistochemical study demonstrated that these cells were positive for leukocyte common antigen, kappa and lambda light chains of IgG, indicating polyclonality of these plasma cells ${ }^{[14]}$.

A sellar mass consisting in clef of cholesterol is strongly suggestive of CPs, Cholesterol is not specific of XH, XGH or CPs neither Rathke's cleft cyst ${ }^{[7-9]}$. MRI findings specifically showed high intensity on T1-weighted images and iso- to low intensity on T2-weighted images relative to white matter ${ }^{[1]}$. Whereas, the high signal intensity on T1-weighted images and low signal intensity on T2-weighted images might depend mainly on protein concentration, not on cholesterol ${ }^{[1]}$.

MRI revealed enlargement of the hypophysis-infundibulum with a cystic component finally diagnosed as PA ${ }^{[1,2]}$. Histologic analysis revealed discontinuation of the epithelial line in the RCC ${ }^{[15]}$, abundant inflammatory cells and fibrosis, compatible with granulomatous inflammation in the anterior pituitary gland ${ }^{[15]}$.

Pituitary abscess has been reported, that pathological specimen from the have a capsule with chronic inflammatory fibrous tissue without tumorous component, or GC cells, hemosiderophages or clef cholesterol, the majority of them have been described secondary infections associated with systemic sepsis, chronic sphenoid sinusitis or PT ${ }^{[1]}$.

Ruptured Rathke's cleft cyst is a rare cause of giant cell granulomatous hypophysitis. Chronic inflammatory reaction is caused by extravased fluid cyst content into the adjacent gland ${ }^{[15]}$. Radiologically, the lesion seemed as an intrasellar mass with a cystic component indistinguishable from a pituitary adenoma with cystic degeneration, have been demonstrated mucins produced by cells lining the cyst wall caused the granulomatous giant cell reaction ${ }^{[6,15]}$.

CPs are a benign intracranial nonglial tumors resulting from a malformation of the embryonic tissue ${ }^{[4,5]}$. Denotes about $6 \%-9 \%$ of brain tumors in children. This tumor forms cyst structures that contain a dense lipoproteinaceus material called as "oil machinery fluid". Little is known about it. In our case we can established the presence of oil vacuoles and oil machinery fluid in both pseudocapsule, and adenohipophysis cells ${ }^{[4,5]}$. This clinical case underlines the difficulties in treatment of recurrent craniopharyngioma in situations where the structural location do not permit aggressive radical surgery ${ }^{[5]}$. Their close proximity to vital structures such as the hypothalamic-pituitary axis and optic apparatus makes them one of the most inspiring and debated management dilemmas in neurosurgery ${ }^{[5]}$. Treatment elections for recurrent CP include repeat surgery, radiotherapy, radiosurgery and intracystic therapies. During the disease develops visual injury, and secondary diabetes insipidus, hypothyroidism and hypocotisolism ${ }^{[1]}$ etc. Xanthogranulomatous change of CPs, containing of cholesterol clefts, chronic inflammatory infiltrates, hemosiderin deposits, macrophages, necrotic, debris and it has been customarily considered a characteristic criteria of the $\mathrm{CP}^{[4,5]}$, amount of cystic components even in the absence of epithelium, or just find machinery oil flow and reactive gliosis and Rosenthal fibers, like our case.

Paulus W et al. ${ }^{[4]}$, proposed that xanthogranuloma (cholesterol granuloma) of the sellar region is clinically and pathologically different from the adamantinomatous CPs. The marked fibrosis (forming a pseudocapsule), complemented by capillary proliferation, and diffuse infiltration by neutrophils, lymphocytes, plasma cells are compatible with the prolonged chronic inflammation with granulation and the epithelial cells of the cystic wall or destruction by the inflammatory process and replaced by granulation or fibrous tissue could be due to rupture of CPs or may be due to involution of the tumor ${ }^{[4]}$. This progression may be seen in association to piloide gliosis shown in some CPs, how the firth biopsy was diagnosed ${ }^{[4]}$. The xantogranulomas development could be measured as natural immunological employment of reduction of tumor growth and progression of disease caused by extravased cyst content into the adjacent gland ${ }^{[4]}$.

We suggested that may be due to rupture of craniopharyngioma and pseudocapsule formation was made with intense inflammatory response of lymphocytes, giant cells and cholesterol clefts. Her vision has improved slightly and MRI revealed no lesion. Nevertheless, new studies are needed to evaluate the efficacy of systemic chemotherapy and radiotherapy treatment or merely the oil machinery fluid content aspiration that could reduce the progression of disease. Because we consider that this fluid is widely antigenic and toxic which could cause damage to the adjacent tissues. 


\section{Conclusion}

We believe that the current patient with a ruptured cyst that took place craniofaringioma however not enough conclusive craniofaringioma material was obtained, having an intense inflammatory response that became more intense until it affects the adenohipophysis. The breakdown of cystic structures in the CP can spend unobserved or can give an intense inflammatory response, where there is not always an external epithelium and only got to see make grants gliosis, inflammation and formation of Rosenthal fibers. The presence of this oil machinery fluid is not always has been observed but suggesting to become toxic to the adjacent tissues.

\section{Conflict of interests}

The authors declare that there is no conflict of interests.

\section{References}

[1] Park SM, Bae JC, Joung JY, et al. Clinical characteristics, management, and outcome of 22 cases of primary hypophysitis. Endocrinol Metab (Seoul). 2014; 29: 470-8. PMid: 25325267. http://dx.doi.org/10.3803/EnM.2014.29.4.470

[2] Leroy C, Karrouz W, Douillard C, et al. Diabetes insipidus. Ann Endocrinol (Paris). 2013; 74: 496-507. PMid: 24286605. http://dx.doi.org/10.1016/j.ando.2013.10.002

[3] Tashiro T, Sano T, Xu B, et al. Spectrum of different types of hypophysitis: a clinicopathologic study of hypophysitis in 31 cases. Endocrine Pathology. 2002; 131: 83-195. http://dx.doi.org/10.1385/ep:13:3:183

[4] Paulus W, Honegger J, Keyvani K, et al. Xanthogranuloma of the sellar region: a clinicopathological entity different from adamantinomatous craniopharyngioma. Acta Neuropathologica. 1999; 97: 377-382. PMid: 10208277. http://dx.doi.org/10.1007/s004010051001

[5] Zada G, Lin N, Ojerholm E, et al. Craniopharyngioma and other cystic epithelial lesions of the sellar region: a review of clinical, imaging, and histopathological relationships. Neurosurgical Focus. 2010; 28: E4.10.

[6] Müller HL, Gebhardt U, Faldum A, et al. Xanthogranuloma, Rathke's cyst, and childhood craniopharyngioma: results of prospective multinational studies of children and adolescents with rare sellar malformations. Journal of Clinical Endocrinology and Metabolism. 2012; 97: 3935-3943. PMid: 22969141. http://dx.doi.org/10.1210/jc.2012-2069

[7] Amano K, Kubo O, Komori T, et al. Clinicopathological features of sellar region xanthogranuloma: correlation with Rathke's cleft cyst. Brain Tumor Pathology. 2013; 30: 233-234. PMid: 23322180. http://dx.doi.org/10.1007/s10014-012-0130-0

[8] Khare S, Jagtap VS, Budyal SR, et al. Primary (autoimmune) hypophysitis: a single centre experience. Pituitary. 2015 ; $18:$ 16-22. PMid: 24375060. http://dx.doi.org/10.1007/s11102-013-0550-9

[9] Himi T, Takano K, Yamamoto M, et al. A novel concept of Mikulicz's disease as IgG4-related disease. Auris Nasus Larynx. 2012; 39: 9-17. PMid: 21571468. http://dx.doi.org/10.1016/j.anl.2011.01.023

[10] De Bellis A, Colella C, Bellastella G, et al. Late primary autoimmune hypothyroidism in a patient with postdelivery autoimmune hypopituitarism associated with antibodies to growth hormone and prolactin-secreting cells. Thyroid. 2013; 23: 1037-41. PMid: 23286389. http://dx.doi.org/10.1089/thy.2012.0482

[11] da Silva BS, Bonin C, Bueno CB, et al. Primary antiphospholipid syndrome and panhypopituitarism: a unique presentation. Acta Reumatol Port. 2012; 37: 272-5. PMid: 23348118.

[12] Ashraf VV, Bhasi R, Kumar RP, et al. Primary Sjögren's syndrome manifesting as multiple cranial neuropathies: MRI findings. Ann Indian Acad Neurol. 2009; 12: 124-6. PMid: 20142860. http://dx.doi.org/10.4103/0972-2327.53083

[13] Andrioli M, Pecori Giraldi F, Cavagnini F. Isolated corticotrophin deficiency. Pituitary. 2006; 9: 289-95. PMid: 17077949. http://dx.doi.org/10.1007/s11102-006-0408-5

[14] Murakami K, Muraishi K, Ikeda H, et al. Plasma cell granuloma of the pituitary gland. Case report. Surg Neurol. 2001 ; 56: $247-51$. http://dx.doi.org/10.1016/S0090-3019(01)00599-7

[15] Roncaroli F, Bacci A, Frank G, et al. Granulomatous hypophysitis caused by a ruptured intrasellar Rathke's cleft cyst: report of a case and review of the literature. Neurosurgery. 1998; 43: 146-9. PMid: 9657201.

http://dx.doi.org/10.1097/00006123-199807000-00092 